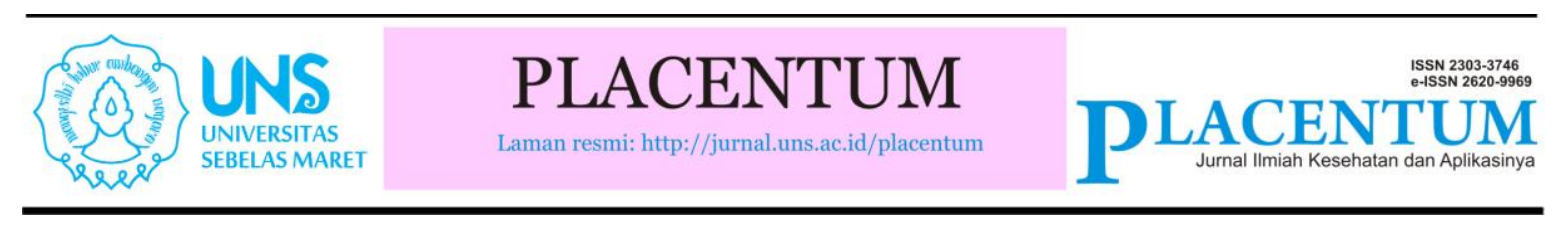

\title{
PEMANTAUAN STATUS GIZI DAN SIKLUS MENSTRUASI PADA REMAJA PUTRI
}

\author{
Monitoring of Nutritional Status and Menstrual Cycle in Adolescents \\ Angesti Nugraheni, Ika Sumiyarsi, Sri Mulyani, Mujahidatul Musfiroh, Erindra \\ Budi Cahyanto
}

Program Studi Kebidanan Program Sarjana Terapan FK UNS

email: angestinugraheni.88@gmail.com

\begin{abstract}
ABSTRAK
Latar Belakang: Siklus menstruasi adalah periode kontinu yang dialami selama proses reproduksi wanita. Ada beberapa faktor yang mempengaruhi siklus menstruasi, salah satunya status gizi. Banyak kejadian overweight atau underweight pada remaja putri berdampak pada ketidakteraturan siklus menstruasi. Tujuan penelitian ini adalah untuk mengetahui status gizi dan keteraturan siklus menstruasi pada remaja putri.

Metode: Penelitian ini dilakukan dengan pemantauan status gizi melalui pengukuran berat badan, tinggi badan, dan keteraturan siklus menstruasi. Subjek penelitian adalah seluruh remaja putri di Program Studi Kebidanan Program Sarjana Terapan sebanyak 27 responden.

Hasil: Hasil pemantauan status gizi menunjukkan bahwa mayoritas remaja putri sejumlah $9(33.3 \%)$ memiliki status gizi normal, 8 (29.7\%) memiliki status gizi kurang, 5 (18.5\%) memiliki status gizi berisiko obesitas, dan 5 (18.5\%) sisanya memiliki status gizi obesitas grade I. Sedangkan hasil pemantauan siklus menstruasi menunjukkan bahwa mayoritas remaja putri mengalami siklus mentruasi teratur yaitu $23(85.2 \%)$ dan 4 (14.8\%) remaja putri mengalami siklus menstruasi tidak teratur.

Simpulan: Status gizi remaja putri mayoritas dengan status gizi normal dan remaja putri lainya mengalami status gizi yang bervariasi. Siklus menstruasi remaja putri sebagian besar teratur dengan beberapa gangguan dalam siklus menstruasi seperti dismenorea dan sindrom pramenstruasi.
\end{abstract}

Kata Kunci : Status Gizi, Menstruasi, Siklus Menstruasi, Sindrom Pramenstruasi. 


\section{ABSTRACT}

Background: Menstrual cycle is a continuous period experienced during the female reproductive process. There are several factors that affect the menstrual cycle, one of which is nutritional status. Many overweight or underweight events in young women have an impact on menstrual cycle irregularities. The purpose of this research is to determine the nutritional status and regularity of the menstrual cycle in young women.

Method: This research is carried out by monitoring nutritional status through measurements of body weight, height, and regular menstrual cycle. The subjects of devotion were all 278/2019 applied study midwifery study program female students.

Results: The results of the nutrition status monitoring service activities showed that the majority of young women were 9 (33.3\%) had normal nutritional status, 8 (29.7\%) had undernourished status, 5 (18.5\%) had risky nutritional status obesity and 5 (18.5\%) the rest have grade I obesity status. While the results of monitoring the menstrual cycle show that the majority of young women experience regular menstrual cycles of $23(85.2 \%)$ and 4 (14.8\%) young women experience irregular menstrual cycles.

Conclusion: The nutritional status of the majority of adolescent girls with normal nutritional status and other girls experiencing varying nutritional status. Girls' menstrual cycles are mostly regular with a number of disorders in the menstrual cycle such as dysmenorrhea and premenstrual syndrome.

Keywords: Nutritional Status, Menstruation, Menstrual Cycles, Premenstrual Syndrome

\section{LATAR BELAKANG}

Menstruasi merupakan proses kompleks yang melibatkan beberapa hormon, organ seksual, dan sistem saraf. Hormon memiliki pengaruh penting dalam menstruasi, jika hormon tidak seimbang maka siklus akan terganggu. Siklus menstruasi merupakan pertanda klinis fungsi reproduksi wanita ${ }^{[1]}$. Panjang siklus menstruasi diketahui sebagai prediktor kesehatan seperti kanker payudara dan faktor risiko kardiovaskular. Siklus menstruasi didefinisikan siklus pendek jika 25 hari, normal 26-34 hari, atau panjang 35 hari. Siklus menstruasi yang tidak normal juga dikaitkan dengan penurunan fertilitas ${ }^{[2]}$. Jarak siklus menstruasi berbeda pada setiap wanita, umumnya berkisar 15-45 hari rata-rata 28 hari dan lamanya berkisar 2-8 hari ratarata 4-6 hari dengan darah yang dikeluarkan berkisar $60-80 \mathrm{ml}$ per siklus ${ }^{[3]}$.

Berat badan sebagai representasi massa lemak tubuh memiliki pengaruh terhadap keseimbangan hormon dan menstruasi. Berat badan berlebih dan obesitas merupakan kondisi abnormal ditandai dengan penumpukan lemak berlebihan melebihi batas kebutuhan skeletal dan fisik yang dapat mengganggu kesehatan $^{[4]}$. Penelitian ${ }^{[5]}$ menyatakan bahwa ada hubungan antara lemak tubuh dengan siklus menstruasi. Jika seorang wanita memiliki berat badan di bawah rata-rata maka hormon dalam tubuh akan berhenti bekerja dan siklus menstruasi pun akan berhenti. Wanita obesitas memiliki peluang dua kali lipat lebih besar untuk mengalami siklus ireguler dibandingkan dengan wanita yang memiliki berat badan normal $^{[5]}$. Berdasarkan data tersebut peneliti tertarik untuk melakukan penelitian tentang pemantauan status gizi dan siklus menstruasi pada remaja putri.

\section{SUBJEK DAN METODE}

Penelitian dilakukan di laboratorium prodi kebidanan sarjana terapan pada bulan Juli - Agustus 2019. Sasaran penelitian adalah semua remaja putri Prodi Kebidanan Program Sarjana Terapan angkatan 2018/2019 sejumlah 27 mahasiswa. Adapun langkah - langkah 
penelitian yang dilakukan yaitu persiapan alat, bahan, melakukan pengukuran berat badan, tinggi badan, status gizi, dan siklus mentruasi kemudian mencatat pada lembar observasi, melakukan analisis data yang telah terkumpul.

\section{HASIL}

Setelah dilakukan kegiatan penelitian pemantauan status gizi dan siklus menstruasi didapatkan hasil sebagai berikut:

Tabel 1. Status Gizi Remaja Putri

\begin{tabular}{lcc}
\hline $\begin{array}{c}\text { Status } \\
\text { Gizi }\end{array}$ & Jumlah & $\begin{array}{c}\text { Persentase } \\
(\boldsymbol{\%})\end{array}$ \\
\hline Normal & 9 & 33.3 \\
Kurang & 8 & 29.7 \\
Berisiko & 5 & 18.5 \\
obesitas & & \\
Obesitas & 5 & 18.5 \\
Total & 27 & 100 \\
\hline
\end{tabular}

Sumber : Data primer diolah, 2019

Status gizi remaja putri di Prodi Kebidanan Program Sarjana Terapan sebagian besar normal sejumlah 9 (33.3\%), remaja putri berisiko obesitas dan obesitas masing-masing ditemukan sejumlah $5(18.5 \%)$.

Tabel 2. Siklus Menstruasi Remaja Putri

\begin{tabular}{lcc}
\hline \multicolumn{1}{c}{$\begin{array}{c}\text { Siklus } \\
\text { menstruasi }\end{array}$} & Jumlah & $\begin{array}{c}\text { Persentase } \\
(\boldsymbol{\%})\end{array}$ \\
\hline Teratur & 23 & 85.2 \\
\hline $\begin{array}{l}\text { Tidak } \\
\text { teratur }\end{array}$ & 4 & 14.8 \\
\hline \multicolumn{1}{c}{ Total } & 27 & 100
\end{tabular}

Sumber : Data primer diolah, 2019

Siklus menstruasi remaja putri di prodi kebidanan program sarjana terapan sebagian besar teratur sejumlah 23 $(85.2 \%)$, sedangkan remaja putri dengan siklus menstruasi tidak teratur sejumlah 4 $(14.8 \%)$.

\section{PEMBAHASAN}

Status gizi adalah keadaan tubuh yang merupakan hasil akhir dari keseimbangan antara zat gizi yang masuk ke dalam tubuh $^{[6]}$. Status gizi dipengaruhi oleh konsumsi makanan dan penggunaan zat- zat gizi di dalam tubuh. Bila tubuh memperoleh cukup zat-zat gizi dan digunakan secara efisien akan tercapai status gizi optimal yang memungkinkan pertumbuhan fisik, perkembangan otak, kemampuan kerja dan kesehatan secara umum $^{[7]}$.

Berdasarkan data hasil wawancara pada remaja putri pola makan teratur ada beberapa remaja yang alergi terhadap makanan tertentu (udang). Faktor langsung yang mempengaruhi status gizi lebih terdiri dari tingkat konsumsi lemak, protein dan karbohidrat, ketidakmampuan tubuh dalam memetabolisme kelebihan lemak, protein dan karbohidrat akan ditimbun menjadi lemak sehingga meningkatkan berat badan. Disamping hasil wawancara data asupan nutrisi/ pola makan, didapatkan pula data keseluruhan remaja putri mengatakan bahwa jarang melakukan olahraga secara teratur. Berdasarkan teori aktivitas fisik ringan meningkatkan resiko status gizi lebih karena tidak seimbangnya pengeluaran energi ${ }^{[8]}$.

Menstruasi adalah pengeluaran darah secara periodik, cairan jaringan, dan debris sel-sel endometrium dari uterus dalam jumlah yang bervariasi. Biasanya menstruasi terjadi selang waktu 22-35 hari dan pengeluaran darah menstruasi berlangsung 1-8 hari. Siklus waktu normal atau teratur 26-34 hari, tidak teratur ( pendek $<25$ hari, panjang

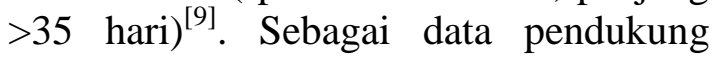
terkait siklus menstruasi berdasarkan data hasil wawancara responden menyatakan $17 \quad(63 \%)$ diantaranya mengalami gangguan dalam siklus menstruasi berupa dismenorea, 25 (93\%) remaja putri mengalami sindrom premenstruasi, dan semua $27(100 \%)$ remaja putri menyatakan bahwa tidak pernah melakukan aktivitas fisik berupa olahraga secara rutin.

Hal ini sejalan menurut hasil penelitian $^{[10]}$. Responden dengan gangguan menstruasi terbanyak dialami meliputi sindrom pramenstruasi $(75.8 \%)$, 
dismenorea $(54.5 \%)$, dan perdarahan di luar menstruasi (36.4\%). Dalam penelitian tersebut juga didapatkan hubungan yang bermakna antara aktivitas fisik dengan gangguan menstruasi. Dua pertiga responden yang mengalami gangguan menstruasi justru aktif secara fisik, sedangkan dua pertiga responden yang tidak mengalami gangguan menstruasi justru tidak aktif. Dalam hasil penelitian $^{[10]}$ juga diketahui bahwa tidak didapatkan hubungan bermakna $(\mathrm{p}=0.191)$ antara IMT dengan gangguan menstruasi. Walaupun demikian, siswi dengan gangguan menstruasi memiliki rerata IMT lebih tinggi (IMT=22.3) dibandingkan siswi yang tidak mengalami gangguan menstruasi (IMT=20.8). Hasil tersebut juga menyebutkan bahwa terdapat hubungan bermakna antara IMT yang tinggi dengan sindrom pramenstruasi serta terdapat hubungan bermakna antara tingginya IMT dan perpanjangan siklus menstruasi $^{[10]}$.

\section{SIMPULAN}

Berdasarkan hasil pemantauan status gizi dan siklus menstruasi pada remaja putri diatas dapat disimpulkan sebagai berikut:

1. Status gizi remaja putri $33.3 \%$ dengan status gizi normal dan prosentase remaja putri lainya mengalami status gizi yang bervariasi (gizi kurang, berisiko obesitas dan obesitas grade I).

2. Siklus menstruasi remaja putri $85.2 \%$ teratur dengan beberapa gangguan dalam skilus menstruasi $63 \%$ remaja putri mengalami dismenorea dan 93\% diantaranya mengalami sindrom pramenstruasi.

\section{SARAN}

Dari simpulan diatas dapat disarankan beberapa hal berikut:

1. Remaja putri sebaiknya menjaga agar status gizinya dalam kategori normal. Hal ini bisa dilakukan dengan mengatur pola dan jenis makanan yang dikonsumsi sehari-hari, serta menyeimbangkanya dengan aktivitas fisik (olahraga) yang teratur.

2. Remaja putri dapat mengurangi gangguan yang dialami dalam siklus menstruasi (sindrom pra menstruasi dan dismenorea) dengan teknik relaksasi juga dengan melakukan aktivitas fisik yang baik.

\section{DAFTAR PUSTAKA}

1. Diaz A, Laufer MR, Breech LL. 2006. Pediatrics: Menstruation in girls and adolescents: using the menstrual cycle as a vital sign;118(5), h:2245-50.

2. Rofiq A. 2009. Persentase lemak tubuh dan lingkar pinggang sebagai faktor risiko bagi ketidakteraturan siklus menstruasi pada remaja Putri (skripsi). Semarang: Universitas Diponegoro.

3. Price SA, Wilson LM. 2006. Patofisiologi konsep klinis prosesproses penyakit (terjemahan). Jakarta: EGC

4. WHO. 2009. Obesity. Available at: https://www.who.int/topics/obesity/e n/

5. Dahliansyah. 2008. Hubungan indeks massa tubuh dan presentase lemak tubuh dengan usia menarche dan dismenore. Skripsi. Semarang: Universitas Diponegoro.

6. Gibson, Rosalinds. 2005. Principles of nutritional assessment second edition. New York : Oxford University.

7. Almatsier S. 2011. Prinsip dasar ilmu gizi. Jakarta : PT Gramedia Pustaka Utama, h: 1-13.

8. Febriani, Reny. 2018. Analisis faktor yang mempengaruhi status gizi lebih remaja di kota malang. Avaliable at: https://repository.unej.ac.id/handle/1 23456789/89257.

9. Prahita YA, Syahredi, Lipoetoe N I. 2017. Hubungan status gizi dengan siklus menstruasi pada mahasiswi fakultas kedokteran universitas 
andalas. Available at: http://jurnal.fk.unand.ac.id diakses Kedokteran Indonesia, Volume 59, Nomor: 7, Juli 2009. Available from: https://s3.amazonaws.com/academia. edu.documents/44385535/653-7071-PB.pdf?response-contentdisposition=inline $\% 3 \mathrm{~B} \% 20$ filename \%3DPrevalensi_Gangguan_Menstru asi_dan_Fakto.pdf\&X-AmzAlgorithm=AWS4-HMACSHA256\&X-Amz- tanggal 2 September 2019.

10. Sianipar, et al. 2009. Majalah Credential=AKIAIWOWYYGZ2Y5 3UL3A\%2F20191126\%2Fus-east1\%2Fs3\%2Faws4_request\&X-AmzDate $=20191126 \mathrm{T041328Z \& X-Amz-}$ Expires $=3600 \& X-A m z-$ SignedHeaders $=$ host $\& X-A m z-$ Signature $=33 \mathrm{e} 94 \mathrm{f} 5 \mathrm{cb} 2 \mathrm{fc} 17 \mathrm{fb} 4 \mathrm{cba} 00$ 4dc712e9078751524e699bde0347bb $7332496614 \mathrm{c} 5$ 